\title{
EPICURO Y EL PLACER
}

\section{Daniel Trapani}

\section{En torno al placer}

En el canto VII de la Odisea, Homero nos ha legado un bello pasaje que expresa, en ecológicas imágenes, el sueño de la felicidad humana:

Crecen allí grandes y florecientes árboles: perales, granados, manzanos de espléndido fruto, dulces higueras y verdes olivos. Los frutos de estos árboles no se pierden ni faltan, ni en invierno ni en verano: son perennes, y el Céfiro, soplando constantemente, a un tiempo mismo produce unos y madura otros. La pera envejece sobre la pera, la manzana sobre la manzana, la uva sobre la uva y el higo sobre el higo ${ }^{l}$.

Este lugar pincelado por Homero es la isla de los feacios, realidad sosegadora para Ulises y esperanza del pueblo griego encarnada en los labios del rapsoda. La isla de los feacios se convierte en símbolo ligado a la felicidad y al placer. Actualizar el hexámetro homérico requería diseñar las condiciones para que el sosiego de Ulises acampara en la cotidianeidad ateniense. Esta tarea urgió a Epicuro, quien, ante un mundo fragmentado como el suyo, asignó a la cuestión del placer una importancia decisiva para

${ }^{1}$ Homero, La Odisea, 113-120, Barcelona, Iberia, p.88. 
su empresa. Meditar y delinear el placer humano es acercarse, por tanto, al diseño ético del Jardín.

Ahora bien, ¿de qué modo concebía Epicuro el placer?. ¿En qué difiere su propuesta de otras, ya formuladas en el mundo griego, particularmente de la doctrina platónica del placer tal como aparece en el Filebo?. ¿A qué se debe la discrepancia de Platón en esta cuestión ?. ¿Tan sólo a una diversa concepción ética sobre el asunto?.

\section{EI placer: bien connatural}

La filosofía moral, reiteradamente, se ha ocupado de caracterizar al 'bien moral', y entre las respuestas acuñadas la posición epicúrea se ha hecho clásica. Para Epicuro, "el placer es principio y consumación de la vida feliz, porque lo hemos reconocido como bien primero y congénito" (Ep.Men. 128). El placer es el protón agathón, el summum bonum, por esto, para Epicuro, ningún placer, de por si, puede ser un $\mathrm{mal}^{2}$, dado que "bien significa lo que es o causa placer" ${ }^{\text {. }}$ El criterio que permite responder "qué es el bien', viene dado por la propia naturaleza de los seres animados. Por boca de Torcuato, Cicerón nos transmite este criterio que hace posible ver al placer como el último y supremo bien:

todo animal, así que nace, apetece el deleite, y goza con él como si fuera bien sumo, (y rechaza el dolor como el sumo mal) y cuanto puede lo aparta de sí y esto lo hace cuando todavía no está depravado, y es la misma naturaleza la que juzga íntegra e

\footnotetext{
${ }^{2}$ Ver Epicuro, $M P$ VIII.

${ }^{3}$ Long, Anthony, La filosofía helenística, Madrid, Alianza Editorial, 1975, p. 68.
} 
incorruptamente. $Y$ por eso niega Epicuro que sea obra de la razón y de la inteligencia el buscar el deleite y huir del dolor. Cree que esto no se juzga, sino que se siente, como el calor del fuego, la blancura de la nieve, la dulzura de la miel, ninguna de las cuales cosas se han de confirmar con razones exquisitas, sino que basta enunciarlas simplemente (...). Y así como, quitados al hombre los sentidos, nada queda, necesario es que la naturaleza misma juzgue lo que es natural o antinatural. Y qué razón percibe la naturaleza para buscar alguna cosa o para huir de ella, sino el placer y el dolor ${ }^{4}$.

Sin embargo, no todo placer tiene carácter perentorio para el Maestro de Samos. Lo que debemos hacer es perseguir aquello que culmine en el mejor placer. 'Debemos' se refiere, en este contexto, a los medios que es menester elegir si deseamos alcanzar con éxito nuestro fin, pues,

... no escogemos todos los placeres, cuando de ellos se sigue para nosotros una incomodidad mayor. Y a muchos dolores los consideramos preferibles a los placeres si, por soportar tales dolores durante mucho tiempo, nos sobreviene un placer mayor. En efecto, todo placer, por tener naturaleza innata, es bueno, pero, sin duda, no todos son dignos de ser escogidos. De la misma forma, todo dolor es un mal, pero no todos deben evitarse siempre ${ }^{5}$.

${ }^{4}$ Marco Tulio Cicerón, Del sumo bien y del sumo mal, I, 30, Tomo I, p. 663. De Obras Completas, (6 Tomos) / Bs.As., Anaconda, 1946. (El traductor castellano omite traducir una frase del texto latino, cuyo original transcribo colocando entre paréntesis el texto no traducido "omne animal simul atque natum sit voluptatem appetere eaque gaudere tu summo bono, (dolorem aspernari ut summum malum) et quantum possit a se repellere").

${ }^{5}$ Epicuro, Ep.Men. 129-130. 


\section{Teoría epicúrea del placer}

$\mathrm{Al}$ asentar el placer como bien primero y connatural, señala Epicuro el objetivo de la ética consistente en precisar aquello que hemos de buscar o evitar para alcanzar la vida feliz. La consecución del placer y la evitación de su contrario, el dolor, guía nuestras elecciones y rechazos de modo natural. La propia naturaleza de los seres animados es la que fija este criterio básico de conducta. Lo afirmado hasta aquí, la postulación básica del placer como bien supremo y la justificación de tal tesis en la natural apetencia de los seres vivos, no aporta nada original en la moral griega. Ambas aserciones habían sido sostenidas por Aristipo de Cirene; mas si el punto de partida no es novedoso, Epicuro supera las tesis cirenaicas en coherencia y perspectiva crítica.

Para Aristipo, la felicidad se define como una adición de placeres de tipo activo, sensibles y sobre todo corporales ${ }^{6}$; si la felicidad consiste en tal adición esto resulta poco estimulante, teniendo en cuenta lo etéreo del instante placentero. Es dudoso que la fruición ocasional de numerosos placeres pueda compensar el conjunto de dolores y temores y el sentimiento de desamparo vital en la existencia de muchos hombres. Conforme a este canon el balance de una vida puede resultar muy negativo; de ahí que uno de los cirenaicos más consecuentes, Hegesias, predicara el suici-

\footnotetext{
${ }^{6}$ Ver Laercio Diógenes, Vidas, opiniones y sentencias de los filósofos más ilustres, Bs.As., Emecé, Tomo I, p. 137-139. Los cirenaicos tienen las siguientes opiniones; "establecen dos pasiones, el dolor y el deleite, llamando al deleite 'movimiento suave' y al dolor 'movimiento áspero", "el fin es un deleite particular, pero la vida feliz es un agregado de deleites particulares pasados y futuros... el deleite es bueno aunque proceda de las cosas indecorosas (... ) pues aunque la acción sea indecente, se disfruta su deleite, que es bueno"..."Que los deleites del cuerpo son muy superiores a los del ánimo".
} 
dio con convicción y efectos persuasivos, ante este perfil del 'gozador' condenado a acarrear agua en vasijas irremediablemente desfondadas.

Epicuro se mueve sobre este trasfondo filosófico, y atiende a las sensatas críticas que mereció Aristipo en la Academia y el Liceo. Sin embargo, ni Platón ni Aristóteles habían logrado elaborar un sistema ético del que pudiera derivarse fácilmente una moral de universal comprensión y aplicación. Como señala Antonio Pasquali, un griego del siglo II a.C., deseoso de hallar en el Libro V de la Ética a Nicómaco alguna definición de 'justicia' que le ayudara a ser más justo, se hallaría en una situación similar a la de un ciudadano de hoy, con instrucción media, que buscase fórmulas similares en la Filosofía del Derecho de $\mathrm{Hegel}^{7}$. En contraposición, Epicuro facilitó el acceso a un sistema de moralidad, al elaborar un modelo accesible de hombre prudente. En esto Epicuro fue un antecedente brillante de la premisa kantiana según la cual en asuntos morales se “... es capaz de llegar a un acuerdo notable de popularidad y acomodación al entendimiento vulgar"8. Convencido de que "la razón humana, en lo moral, aun en el más vulgar entendimiento, puede ser fácilmente conducida a mayor exactitud y precisión"9.

Con este horizonte a la vista, asienta Epicuro sus principales tesis:

${ }^{7}$ Ver Pasquali, Antonio , La moral de Epicuro, Caracas, Monte Avila, 1970, p. 12.

${ }^{8}$ Kant, Immanuel, La fundamentación de la metafísica de las costumbres, México, Editorial Porrúa, Prólogo, p, 18.

${ }^{9}$ Ibid. 
i) El placer fundamental no es la agitación de nuestra sensibilidad (placer cinético o genético), sino el "placer catastemático, que sigue a la ausencia de turbación, considerado por Epicuro como el fin supremo"10. La idea de constitución (katastema) responde al conjunto de las partes que, en equilibrio, conforman un organismo vivo. En un pasaje epicúreo De las elecciones se opone este ideal de placer a los sentimientos de alegría y goce: "La falta de turbación anímica y de dolor son placeres catastemáticos o calmosos; por el contrario, la alegría y el goce, se ve con claridad que son (placeres) en movimiento por su misma actividad"11

El placer como estado de plenitud humana es contrario al movimiento, a lo incesante y a lo impetuoso. El estado placentero equivale al de la simple bonanza, calmo fluir de representaciones y vivencias: opuesto al activismo aristotélico que se disponía a gobernar pasiones y potencias a través del hábito virtuoso. Sin embargo, esta inactividad o reposo no ha de asemejarse a la torpeza o amodorramiento (SV II).

ii) No hay medio -como el sostenido por Aristipo- entre placer y dolor, ambos se relacionan como contradictorios, no como contrarios, se niega así un estadio neutro, intermedio, entre placer y dolor, ya que el "límite de la magnitud de los placeres es la eliminación de todo dolor. Donde haya placer, por el tiempo que dure, no existe, dolor o pesar o la mezcla de ambos" (MP III); es por ello que "no admitió Epicuro que hubiese medio entre el dolor y el placer. Lo que a algunos les parece medio, es decir, el carecer de todo dolor, no sólo es deleite, sino el deleite sumo"12.

\footnotetext{
${ }^{10}$ Laercio Diógenes, Op.Cit. U, 87.

${ }^{11}$ Laercio Diógenes, Op.Cit., 136-139.

${ }^{12}$ Marco Tulio Cicerón, Op.Cit. I, 38 Tomo 1, p. 666.
} 
La supresión del dolor no es una condición de posibilidad que prepare la aparición de otro estado diverso, sino que no sentir dolor y experimentar placer son dos modos de expresar una única realidad.

iii) El placer es algo positivo; en cuanto connatural a nuestro organismo vivo el placer es innato, mientras que el dolor es extraño. "Ningún placer por sí mismo es un mal" (MP VIII), ya que, "en efecto, todo placer, por tener naturaleza innata, es bueno..." (Ep.Men. 129). Perseguir el placer y rehuir el dolor se asume como norma de nuestro actuar. La 'hedoné' epicúrea coincide con el vivir feliz, y no es la simple suma de placeres particulares, sino el estado natural de los seres vivos; mientras el dolor, tanto físico (1ýpe) como espiritual (pónos), irrumpe en la armonía placentera del organismo impidiendo su actividad natural. Hallamos en Epicuro un talante optimista al adjetivar al dolor como 'extraño' a la vida natural, lejos se encuentra pues de la concepción pesimista del existir como acontecer penoso.

iv) El placer, una vez eliminado el dolor, sólo puede modificarse cualitativamente, pues "no se acrecienta el placer en la carne, una vez que se ha extirpado el dolor por alguna carencia, sino que sólo se colorea" (MP XVIII). Aparece aquí con claridad la influencia de Aristóteles, según el cual el placer "es un todo, y en ningún momento podría tomarse un placer, que después de un intervalo más largo, se perfeccionase en cuanto a su forma"13. Ya que "el placer es del número de las cosas enteras y completas"14.

v) Los deseos adquieren en Epicuro un orden jerárquico diseñado

${ }^{13}$ Aristóteles, Ética Nicomáquea, Madrid, Gredos, 1985,1174 a 17-20. ${ }^{14}$ Aristóteles, Op.Cit., 1174 b5-10. 
por la phýsis humana. Se reconoce, en su reflexión sobre el deseo, la influencia democrítea ${ }^{15}$ y aristotélica ${ }^{16}$. La elaboración de un criterio que discrimine, conforme a la phýsis, entre deseos buenos y malos, se deberá a una cierta perversión del deseo incapacitado para regularse negativamente a raíz de la hueca opinión humana, propensa a representar lo contingente, sub specie necessitatis. Será el cálculo (logismós) prudente, el que deberá operar en base a una adecuada clasificación jerárquica de los deseos. Epicuro propone la siguiente ordenación:

1. Deseos naturales y necesarios: Se originan por reacción al dolor y una vez satisfechos restauran, en el cuerpo y en el alma, el equilibrio necesario. Son fáciles de satisfacer, y son indispensables para el bienestar del cuerpo, para la felicidad (prós eudaimonían) y para la subsistencia vital.

2. Deseos naturales, pero no necesarios: No surgen como reacción al dolor, sino como variación del placer, por tanto no comportan dolor si no son satisfechos. Son placeres difíciles de satisfacer, y se refieren al placer del goce de la naturaleza por los sentidos, e incluyen los deseos relativos al goce del amor.

3. Deseos no naturales ni necesarios: No surgen como reacción al dolor ni como coloración del placer. Son inconsistentes y dañinos, producto de la vana opinión. Así, el deseo de coronas, halagos y estatuas ${ }^{17}$.

El sabio ha de cuidarse del asalto furibundo de deseos no

${ }^{15}$ Ver Demócrito, Fragmentos, Diels Kranz. 68 - 223,224,234,235.

${ }^{16}$ Ver Aristóteles, Op.Cit., 1118 b8, 1119 a2 1.

${ }^{17}$ Ver Epicuro, MP XXIX, XXX; Ep.Men. 127-128 
discriminados previamente ${ }^{18}$. Sin embargo, lejos está Epicuro del rigorismo represivo del deseo, la naturaleza pide ser satisfecha, pero sus exigencias básicas son mínimas y esenciales, pudiendo, quien las satisfaga, "rivalizar con Zeus en felicidad" (SV 33).

vi) El tiempo, como espacio recreado desde la memoria, tiene en Epicuro vital gravitación en su distanciamiento del 'goce' de Aristipo. Los cirenaicos se instalaban en la pura presencia del objeto, en su inmediatez, por lo cual el placer se revestía de una efímera permanencia. A este evanescencia de lo placentero apunta la concepción epicúrea del tiempo, superando la puntualidad del goce cirenaico. La pura teoría del presente queda recogida en el fuero de la memoria, la reflexión y la espera. Es así que "un tiempo ilimitado y un tiempo limitado contienen igual placer, si uno mide los límites de éste mediante la reflexión" (MP XIX). Asimismo, el deseo de prolongar el placer en una temporalidad infinita es desmantelado, pues "para nada necesitamos ya un tiempo infinito" (MP XX).

\section{Epicuro y Platón: la riqueza del diálogo}

La influencia que las grandes filosofías de la Academia y el Liceo tuvieron sobre el pensamiento epicúreo no fue debidamente reconocida durante siglos. A partir de los trabajos de $\mathrm{H}$. Bignone, Il Aristote perduto e la formazzione filosofica di Epicuro de 1936, se hace consciente la relación a establecer entre Epicuro y el Aristóteles de los primeros escritos, relación que estudiosos posteriores a Bignone, extendieron al Aristóteles maduro.

Si se tiene en cuenta el testimonio de Cicerón en De natura deorum sobre un tal 'Pánfilo, discípulo de Platón', como primer maestro de Epicuro, y el posible encuentro con Jenócrates, sucesor de Platón en la Academia, resulta viable relacionar la postura 
del Jardín con los diálogos platónicos. Sin embargo, la filosofía epicúrea no es un arma arrojada contra Platón, ni su reflexión está signada por el "intento de 'contestar' el pensamiento" 19 platónico. Si bien no es soslayable la oposición entre ambos, extremar el enfrentamiento impide rescatar nociones comunes. En lugar de, este 'polemós', es el diálogo quien ha de mediar. La polémica estéril ha de ser reemplazada por el diálogo textual. Epicuro ha pensado lo mismo que Platón, mas no del mismo modo; lo primero abre el diálogo, lo segundo lo enriquece en matices y contrastes.

El sabio de Samos repiensa el placer conservando categorías de análisis similares a las del 'divino' Platón. Es la arquitectura de la composición la que produce en nuestros días diversas melodías en cada caso, sin embargo, la grama de ambas se presenta con similares notas. Son notas comunes, lo finito (péras) y lo ilimitado (ápeiros), el cálculo (logismós) y el deseo (epithymía), la mesura (métron) y la génesis. La configuración del Filebo ha dado a la historia del pensar una melodía del placer que guarda semejanza a nivel de sus 'notas' conceptuales con la melodía del Jardín.

A fin de precisar las relaciones entre ambas arquitecturas teóricas he de referir en primer lugar la teoría platónica del placer, para sugerir una interpretación que dé cuenta del diverso edificio eudemónico erigido en cada caso.

${ }^{18}$ Ver Epicuro, SV 80

${ }^{19}$ Ojeda, Rafael; Olabuenaga, Alicia, Epicuro, Madrid, Alhambra, 1985, p. 23. 


\section{A. 'Filebo' o la niñez del placer}

El 'Filebo' es uno de los últimos diálogos de Platón. Versa sobre el problema de saber si lo que es bello, lo que conduce a una vida feliz es -como sostiene Filebo- el placer, o más bien la sabiduría, el intelecto o la memoria. Sócrates observa, al inicio, que el placer tiene múltiples formas aunque en todos los casos se le llame con el mismo nombre. Este contexto de multiplicidad y mismidad coloca al placer en la perspectiva más amplia de las relaciones entre lo 'uno' y lo 'múltiple'. Para ilustrar esta relación recurre a la figura del sonido (Fil. l17b) que emitido por la boca es uno y, por otro lado, de infinita diversidad. No basta, sin embargo, decir que el sonido es uno e infinito, habrá que precisar además qué identidad y qué diferencia aloja en su seno. El número, al ser pluralidad determinada, mediará permitiendo el pasaje de infinito a unidad y viceversa.

Tras este aparente rodeo Sócrates retoma la cuestión inicial, invocando un discurso oído en el pasado, discurso según el cual el bien no es ni el placer ni la sabiduría sino una tercera cosa distinta y superior a ambas. El bien es lo más perfecto que existe y todo ser consciente lo busca, sin embargo no hay ningún placer en la vida sapiencial, ni sabiduría en la vida placentera (Fil. 20e); por tanto ambos, sabiduría y placer, requieren un complemento, no siendo entonces el verdadero bien (Fil. 20c). Si bien el placer y la sabiduría son bienes (agathón) ninguno de ellos es 'lo Bueno' (tagathón) (Fil. 13b). Una vida de goce integral requiere, para ser plenamente humana, consciencia, inteligencia y opiniones verdaderas (Fil. 21c). Y una vida en la que hubiera únicamente ciencia, inteligencia y memoria, y que no participase de placer alguno, se instalaría en la apatía (Fil. 22e). 'Lo bueno' (tagathón) no es por tanto Afrodita la diosa de Filebo, ni la 'Inteligencia' defendida por Sócrates en diálogos anteriores (Fil. 22c). Dado que ni la 'inteli- 
gencia' ni el 'placer' pueden ocupar el primer lugar en la jerarquía de la vida ideal, queda por dilucidar a cual de los dos corresponde el segundo puesto, ya que el primero corresponde a la vida 'conjunta' o 'mezclada' de ambos (Fil. 22d).

Con el propósito de asignar este segundo sitial procede Sócrates a señalar la función del placer y la inteligencia en cuanto posibles causas de la vida 'conjunta'. Según su criterio ordenador el segundo puesto corresponde a la 'Inteligencia', relegando al 'placer' más allá del tercer lugar. Sócrates sugiere a Filebo y Protarco -sus interlocutores- cuatro géneros que definirán la jerarquía iniciada, éstos son: *infinito (ápeiron), *finito (péras), *esencia mezclada y engendrada y * causa de la mezcla. En el género infinito se incluye todo aquello que sin cesar tiende hacia lo más o lo menos, según esto tanto el placer como el dolor pertenecen, por naturaleza, a este género (Fil. 28a). Por el contrario, todo lo comparable a un número, es decir, lo igual, lo doble, etc., se incluye en lo finito, y es en este género que hallamos a la 'sabiduría, ciencia e inteligencia'.

Aún en el mismo seno del placer, opera Sócrates una distinción basada en la pureza o mezcla de los mismos; a los placeres impuros (mezclados) se oponen placeres puros, entre los que evoca la plenitud provocada por los colores bellos y las perfectas formas geométricas. Esta jerarquía reside en la mayor o menor cercanía a la verdad, de allí que el ínfimo placer puro es preferible a una gran cantidad de placer combinado, al atribuir "en el razonamiento desmesura a los placeres intensos, y a sus contrarios, la mesura" (Fil. 52c-d).

Se aborda, a partir de Filebo 53d, un planteo óntico que resulta medular para la interpretación acerca de la diversa postura de Platón y Epicuro en relación al placer. Llega a escena en el 
diálogo la distinción entre lo que es 'en sî' y 'por sî' (autó kath' aúto) y lo que tiende siempre hacia otra cosa. Lo primero -esenciatiene un carácter sagrado del que carece el segundo -génesis-. El placer no tiene nada de esencial (Fil. 54d), pues "está siempre en génesis,... no tiene consistencia alguna" (Fil. 53c). Dado que la génesis se da siempre en orden a la esencia, y no a la inversa, los instrumentos y materiales se emplean en orden a la esencia. Sócrates recuerda así una distinción que recorre, todo el corpus platónico y que muestra que toda explicación tiene valor en relación a 'lo que se explica', lo que se alinea tras 'lo explicado' tiene sólo status de 'medio'. Quienes se decidan por el dominio de la génesis -por ejemplo, los seguidores del placer como supremo bien- han de ser considerados inferiores a los que desean una vida en la que el pensamiento en su mayor pureza ocupa el primer lugar. Aún cuando, recordémoslo, esta vida de total 'pureza' sapiencial no es accesible al hombre.

Al acercarse al final del diálogo Sócrates recapitula y reconsidera la cuestión inicial: la jerarquía a partir de lo 'Bueno' (Fil. 65a). Delineados ya los ingredientes de lo 'bueno', esto es, belleza (kállei), conmensuración (symmetría) y verdad (aletheía), procede a proclamar el orden definitivo. Comienza señalando lo que uno ha de adquirir a fin de captar lo 'bueno'. Estos instrumentos ocupan los dos primeros puestos: i) Lo pertinente a mesura (métron), lo mensurado (métrion) y lo oportuno (kaírion) (Fil. 66a); ii) Lo relativo a lo conmensurado: lo bello, lo perfecto, lo suficiente (Fil. 66b). Continúa Platón la enumeración jerárquica procediendo a ubicar en los puestos subsiguientes 'lo adquirido' mediante los 'instrumentos de captura' mencionados en primer y segundo lugar; iii) entendimiento, sapiencia (Fil. 66a); iv) ciencias, artes, opiniones correctas (Fil. 66b-c); y v) placeres indoloros, placeres puros del alma, ya provenientes de la ciencia o de las sensaciones (Fil. 66c). 
Este orden definitivo manifiesta el relegamiento del placer al quinto puesto y denuncia lo impropio de asignarle el primero como pretendía Filebo. Por otra parte, el aceptado en el quinto lugar es el placer 'puro', alejado del reino de las necesidades. Pues los impulsos naturales en que descansa la supervivencia del individuo, resultan identificados con sus manifestaciones más extremas y sometidos a dura diatriba. El placer, en consecuencia, se revela en el diálogo como lo más inconstante e infantil, por lo cual hay que guardarse de él como del mayor impostor, "cual si los placeres fueran niños desprovistos hasta de un mínimo de inteligencia" ${ }^{20}$.

\section{B. Ubicación del placer: \\ Una cuestión de supuestos "No éticos"}

Puede asignarse a la noción de 'límite' un rol relevante en la estipulación de la madurez humana y, recurriendo a este concepto, cifrar la adultez psicológica del carácter en la aceptación de los límites propios y ajenos. Niñez y adolescencia estarían signadas, según esto, por un desconocimiento o negación de esos límites y por una desmesura en su transgresión. Así también podríamos, mutatis mutandi, estimar la madurez de una propuesta ética en la medida de su consideración del concepto 'límite'. Pensar el 'límite' de lo propio y lo ajeno, constituiría entonces vara de 'adultez' para un sistema ético; confinando al reino de la niñez y adolescencia éticas, los programas morales en los que el señorío y la autoafirmación se tornan insatisfacción y desmesura.

Según esto, podemos atribuir tanto a Platón como a Epicuro, quienes asentaron en la noción de 'límite' los cimientos de sus sistemas éticos, status de 'moralistas maduros'. Platón hace

${ }^{20}$ Platón, Filebo 65 c-d (el subrayado es mío). 
de 'límite' (péras) el principal de los géneros (Fil. 116c, 23c, 27c); y Epicuro en todos sus escritos hace girar su propuesta sobre el cálculo prudente del 'límite' de los bienes (Ep.Mem 133), de los deseos y dolores (MP X), de la vida (MP XXI), del placer (MP $\mathrm{XX}$ ), y de la magnitud de los placeres (MP III). Sin embargo, si bien ambos han pensado el límite lo han hecho según vías diversas que hemos de precisar. Sólo estas vías divergentes permiten clarificar, por un lado, la discordante evaluación del placer al que uno concibe como un niño sin inteligencia y el otro como el supremo bien del hombre maduro, y por otro, la coincidente valoración del límite. La cuestión así planteada puede reformularse en estos términos: ¿qué es lo que promueve en Epicuro la aceptación del placer y en Platón su relegamiento, siendo que ambos construyen su propuesta sobre el 'limite' y su 'cálculo' como núcleos teóricos?. En lo que sigue trataré de zanjar esta cuestión.

Platón al considerar si el placer ha de estimarse como el sumo bien, y su contrario, el dolor como el máximo mal, concluye que "ambos son del género 'infinito' (ápeiron)" (Fil. 28a y 41d), siendo esta infinitud que especifica al placer algo que le corresponde "por naturaleza (pephykós)" (Fil. 27a). El placer, según manifiestan los textos, es ilimitado (hedoné dé apeirós) (Fil. 31a). Más esta 'ilimitación' atribuida por Platón al placer pudiera provenir de algo 'extrínsecó' al placer mismo. Ante esta posibilidad Platón se ocupa de precisar el carácter de tal ilimitación: ésta no proviene de algún agente externo sino que está enraizada en el propio placer el cual es ilimitado "de por sí (en autó)" (Fil. 31a). La inteligencia, la mesura y todo lo semejante pertenecen, en cambio, al género de lo 'finito'. Ambos géneros, finito e infinito, son separables en el análisis platónico, y su combinación como "algo 'uno' resultante de la mezcla de ambos" (Fil. 23d) conforma un tercer género. Si bien el diálogo considera inconveniente la elección de una vida de puro placer (del género infinito) o de exclusi- 
va posesión sapiencial (del género finito), y postula la vida mezclada (tercer género) de ambas como la de elección adecuada, no por ello deja de considerar, a nivel de posibilidad, la opción por el puro placer o la pura sabiduría como proyectos de vida ${ }^{21}$. Esta separación que el análisis del Filebo permite entre vida placentera y vida sapiencial, aun cuando sea a nivel de posibilidad, es consecuencia directa de la exterioridad del 'cálculo' (logismós) y el 'límite' (péras) respecto al placer.

Otra y distinta es la relación establecida por Epicuro entre la 'vida placentera' y la 'vida de la inteligencia', pues aprendizaje y goce no se hallan separados -como en Platón- por la labor analítica. La alegría y el conocimiento conviven en la prédica del filósofo del Jardín, "pues no se goza después de haber aprendido, sino que gozar y aprender se dan conjuntamente (áma)" (SV 27). Si para Platón el optar por pureza sapiencial o por la pureza hedónica, aun cuando posible, resultaba inconveniente; para Epicuro la misma posibilidad de la separación aparece vedada, ya que, "no es posible vivir placenteramente sin vivir sensata, honesta y justamente; ni vivir sensata, honesta y justamente sin vivir placenteramente. Quien no consigue tales presupuestos, no puede vivir con placer". (MP V).

La mezcla presentada como tercera vía por Platón, supone la exterioridad y la preexistencia de los elementos (placer e inteligencia) antes de toda mixtura ${ }^{22}$; en cambio, la relación en Epicuro se hace intrínseca al adverbializar la coexistencia de goce e inteligencia mediante la simultaneidad que otorga el término 'con

${ }^{21}$ Ver Platón, Filebo 21-22 y 60 d-3e

${ }^{22}$ En Filebo 61c, Platón compara al placer con la miel y a la sabiduría con el agua, elementos que se mezclan de modo análogo a la mezcla de placer y sabiduría. 
juntamente' (áma) (SV 27).

Según Platón, la 'tercera vida', mezcla de sabiduría y placer, posee naturaleza limitiforme (pérato eidous) (Fil. 25d), ya que instaura lo delimitado por el límite en lo ilimitado. La inteligencia y su séquito ciñen en límites estrictos lo que es de suyo ilimitado, el placer. Mas este límite es exterior al placer mismo, "por no tener ni placer ni saciedad intrínseco un límite" (Fil. 26b). El orden y la mesura provienen del entendimiento (nous) (Fil. 30b-e) y no del placer que, de suyo, caería en la desmesura, el hartazgo y la insolencia, pues "nada se encuentra entre las cosas que, de natural, sea más desmesurado que placer" (Fil. 65d).

El Jardín, por su parte, concibe la relación mesura-placer en términos diversos a los platónicos. La exterioridad que ambos guardan en el Filebo se hace simultánea coexistencia en la escuela helenística. Si bien Epicuro no recurre a la categoría de género para asignar un lugar al placer y a la inteligencia, sí hace uso de las nociones de finito e infinito. Así como para Platón el límite proviene del cálculo, exterior al placer (Fil. 21c, 26b), para Epicuro es la ilimitación la que procede de algo exterior al placer, ya sea de la consideración carnal,

La carne concibe los límites del placer como ilimitados y querría un tiempo ilimitado para procurárselos (MP XX);

ya de las vanas opiniones (dóxa pseudés),

No el vientre es insaciable, como la mayoría afirma, sino la opinión falsa sobre la infinita (a-orístou- $\sin$ límites) avidez del vientre (SV 59).

Incluso la riqueza -ayer y hoy, sosías del placer- recibe su ilimitación de las 'vanas opiniones', pues la riqueza no es un mal 
en sí a los ojos de Epicuro, más aún,

La riqueza acorde con la naturaleza está delimitada y es fácil de conseguir. Pero la de las vanas opiniones se derrama al infinito (MP XV).

De este modo, Epicuro recupera como ideal la vida placentera en la que el 'límite' es un momento constitutivo e interno, y no algo sobreañadido desde fuera.

Esta divergencia entre Platón y Epicuro a la hora de considerar la relación límite-placer, extrínseca para el primero e intrínseca para el segundo, no se resuelve desde la consideración ética, pues no es un planteo 'ético' sino óntico el que da cuenta de sus diversas posturas. Recordemos que Platón inicia en Filebo 53d un rodeo óntico, capital para el desenlace del diálogo, al sostener que hay dos maneras de ser, una augusta, la otra deficiente. Y es el razonamiento el que nos muestra

que hay cosas que existen siempre por razón de otro, pero que hay siempre algo por gracia de lo cual (éneka) se hace lo que, en cada caso, se hace (Fil. $53 e$ ),

así por ejemplo, el arte naviero es en favor del barco. Sí consideramos ahora dos cosas apareadas como esencia y génesis, veremos que 'génesis' siempre aparece dispuesta en favor de alguna esencia. Y como todo ente pertenece a génesis o a esencia, habrá que precisar en qué lote se incluye al placer. Sócrates, aceptando la opinión de gente sutil, incluye al placer dentro de génesis, pues no hay en él nada esencial. Es por ello que quien convierte a 'génesis' en su fin no merece más que burla como respuesta (Fil. 54d) y es en virtud de esto que Protarco rechaza a quienes eligen como fin a los placeres (génesis), pues al ver “...a alguien regodeándose 
en ellos descubrimos lo que tienen de ridículo o lo que los sigue de superlativa indecencia" (Fil. 65e).

Considerado ónticamente el placer carece entonces de los límites precisos que caracterizan y definen la esencia emparentada con lo eidético. Por ser 'génesis', el placer se inscribe en la fluencia de un proceso, y el orden que lo convierte en estado configurado no está ínsito en el proceso sino que le sobreviene desde fuera, como el agua austera a la miel al mezclarse con ésta ${ }^{23}$.

Epicuro repiensa el 'placer' del Filebo desde una distinta clave óntica, clave que recupera las nociones de esencia y génesis en un engrama novedoso. Conforme a las categorías platónicas según las cuales a 'esencia' pertenece aquello en virtud de lo cual se hace algo- ${ }^{24}$ el placer, propuesto como ideal por Epicuro, pertenecería al reino de la esencia, pues el papel que le asistía como principio (arjé) y fin (télos) nada tiene que ver con el fluir de la génesis. El maestro del Jardín es claro al respecto: "el placer es principio y consumación de la vida feliz" ${ }^{25}$, consistiendo este placer en el estado (placer catastemático) "de no sufrir en el cuerpo ni ser perturbados en el alma" (Ep.Men. 131), y no en el placer cinético (proceso genético de la sensibilidad), y menos aún en el goce de los corruptos.

Excluido el placer (catastemático) del ámbito de la génesis, Epicuro puede otorgarle límites (hóros) intrínsecos que posibilitan su definición (horismós) en el terreno de la esencia. La ilimitación genética del Filebo se hace en Epicuro limitación cons-

\footnotetext{
${ }^{23}$ Ver Platón Filebo $61 \mathrm{c}$.

${ }^{24}$ Ver Platón, Filebo 53 e.

${ }^{25}$ Epicuro, Ep. Men. 128 (el subrayado es mío).
} 
titutiva, enalteciendo como bien primero aquel placer relegado por Platón en la jerarquía eudemónica del Filebo.

\section{Consideraciones Finales}

Algunos intérpretes de Epicuro, Pasquali entre ellos, han analizado al maestro de Samos desde los presupuestos ónticos del platonismo firmemente arraigados en la metafísica occidental, y han juzgado la hedoné epicúrea desde estos presupuestos. Conforme a esto, la razón se erige en la encargada de regular negativamente al placer, ya que éste "en su dimensión prelógica, funciona ...a la manera de impulso en estado natural confuso, como un aóriston o ilimitado, incapaz de autorregularse "negativamente"'26. Será la mente quien imponga "un orden y límites equilibrados (péras) en la positividad desenfrenada de la hedoné instintiva inferior" ${ }^{27}$, pues el placer, como principio motor, es "siempre incapaz de autorregularse"28. Si bien el instinto no ha de rechazarse, no hay que olvidar, sin embargo, que el placer "es tendencialmente ilimitado y ciego"29. Pasquali recurre, a fin de ilustrar su postura, al ejemplo del recién nacido ${ }^{30}$ quien se halla lejano a una conducción racional de su actuar. Ahora bien, ¿no es éste un contraejemplo precisamente, toda vez que el recién nacido, una vez saciado, rechaza ese 'plus' de placer que los mayores le ofrecen?. ¿Podemos

${ }^{26}$ Pasquali, Antonio, Op.Cit., p, 46.

${ }^{27}$ Pasquali, Antonio, Op.Cit., p. 48.

${ }^{28}$ Pasquali, Antonio, Op.Cit., p. 47.

${ }^{29}$ Pasquali, Antonio, Op. Cit., p. 48 (el subrayado es mío).

${ }^{30}$ Ver Pasquali, Antonio, Op. Cit., p. 45. 
hablar con sentido de un recién nacido glotón o desmesurado?. ¿No es esto tan disparatado como asignarle prudencia o magnanimidad a un neonato?.

En una interpretación como la de Pasquali que se ha transformado casi en escolar, Epicuro aparece cercado entre Platón y Freud, entre la razón y el instinto, la mesura y la ilimitación. Desde la arquitectura del Filebo que ha diseñado buena parte de nuestras categorías, se vuelve a asociar la ilimitación al placer. Esta propuesta no me parece sostenible, y esto en función de algunas consideraciones y distinciones a las que habitualmente no se atiende, y que, de respetarse, permitirían delinear más firmemente los rasgos propios de la reflexión moral epicúrea.

Una de esas distinciones pertinentes a la hora de analizar a Epicuro es la que cabe efectuar entre placer y deseo. Es Locke quien recoge, en su Ensayo sobre el entendimiento humano, una tradición iniciada en Demócrito, tradición que concibe al deseo como un estado de inquietud o malestar fijado en algo ausente. Demócrito de Abdera ya había identificado al deseo, impulso prelógico del actuar, con el desenfreno o desmesura (amétros). El desear con insatisfacción permanente, prelógica y ciega, reviste en Demócrito carácter de infinitud, ya que "propio de un niño y no de un hombre es desear con desmesura" ${ }^{31}$. El deseo (epithymía), asociado por Demócrito a la niñez y definido por Aristóteles como apetito de placer $^{32}$, es el que se reviste de infinitud, ilimitación y desmesura en la concepción epicúrea. No es el placer el insaciable, sino el deseo. De allí la dialéctica paradojal del deseo de placer, pues se conjuga en él la avidez infinita (deseo-epithymía) de lo de suyo finito (placer-hedoné). Esta desproporción entre el

\footnotetext{
${ }^{31}$ Demócrito, Fragmentos, Diels-Kranz 68 B 70 (1 subrayado es mío)

${ }^{32}$ Ver Aristóteles, Acerca del alma, L. II, Cap., $3^{\circ}, 414$ b4ss.
} 
deseo y su cumplimiento será reinterpretada por Agustín de Hipona desde una clave trascendente: 'Nos hiciste para Ti Señor y nuestro corazón está inquieto hasta que descanse en Ti' (Fecisti nos ad Te, et inquietum est cor nostrum donec requiescat in Te). En el cristianismo el deseo, infinito e inquieto, tendrá un Infinito positivo como télos, un fin Infinito ${ }^{33}$. Pero desde la inmanencia del pensar griego, el deseo ávido e inquieto se desborda en ilimitación y desmesura.

Son los deseos los que han de limitarse, pues el hombre es infeliz "por el deseo ilimitado y vano" (aóriston epithiymían) ${ }^{34}$, y este límite sí es extrínseco al deseo, extrínseco como el agua a la miel en el Filebo (Fil. 61c). De acuerdo a esto, Epicuro aconseja de este modo a un discípulo: "si quieres hacer rico a Pitocles, no aumentes sus riquezas sino limita sus deseos" 35 , ya que "en relación a los deseos ilimitados la mayor riqueza es la pobreza" ${ }^{36}$. La imagen del tonel de las Danaides es figura del deseo como apetito de placer y no del placer mismo, pues "la ingratitud del alma hace, al ser viviente ávido de variar hasta el infinito los alimentos"37. Dado que el deseo es apetito del placer, las interpretaciones habituales de Epicuro han endosado al placer como télos los caracteres del deseo. Para Epicuro, sin embargo, la ilimitación corresponde al deseo, lo que le permite referirse a deseos no naturales, pero sin mencionar nunca placeres no naturales, ya que todo placer es

${ }^{33}$ Ver Heimsoeth, Heinz. Los seis grandes temas de la metafísica occidental, Revista de Occidente, Madrid, 1974, p, 73 y ss.

${ }^{34}$ Epicuro, Fragmentos, Usener 485 (el subrayado es mío).

${ }^{35}$ Epicuro, Fragmentos, Usener 135 (el subrayado es mío).

${ }^{36}$ Epicuro, Fragmentos, Usener 202 (el subrayado es mío).

${ }^{37}$ Epicuro, SV 69. 
connatural. Siendo la naturaleza humana limitada, la connaturalidad del placer epicúreo aparece imbricada a la finitud de la physis, y la no naturalidad de algunos deseos a la infinitud del apetito.

Sin embargo, esta distinción entre placer y deseo no acalla la crítica acerca de la desmesura del placer. Si el placer es connatural, ¿por qué hemos de rechazarlo en alguna ocasión?; si el dolor es extraño al hombre, ¿por qué aceptar o elegir algunos dolores?. Pareciera que la connaturalidad del placer no es garantía de su autonomía y que es preciso un comando heterónomo que discrimine la conveniencia de los diversos placeres. Ahora bien, ¿cuál sería el canon utilizado por este tribunal heterónomo cuya labor es cribar los diversos placeres?. ¿Deberá este tribunal juzgar a los placeres por lo que son en sí?. Si esto fuera así, la exterioridad de la mesura que Epicuro aparea al deseo, reaparecería ahora asociada al placer mismo. Y la tesis epicúrea aquí defendida, según la cual el placer pertenece al orden de lo finito, se vería seriamente amenazada.

Presentada la objeción, intentaré aclarar de qué modo puede defenderse la no desmesura del placer junto a la necesidad de un tribunal externo al placer que dictamine la estrategia del actuar humano. Para esto es esencial dilucidar cuál es el canon conforme al que los placeres son juzgados. No se trata, según Epicuro, de un juicio sobre los placeres en sí, sino sobre las consecuencias que se siguen tras la satisfacción de los placeres. Este tribunal, que es la razón bajo el rostro del cálculo (logismós), no juzga al placer de modo concomitante sino que al anticipar las posibles consecuencias de la elección intenta transformar los eventos futuros en concomitancias diferidas del placer presente. Esta idea responde a la postura socrática,.presentada por Platón en el Protágoras, postura a la que Platón criticó en diálogos posteriores como Filebo o República. El logismós epicúreo encuentra un cla- 
ro precedente en el 'arte de medir y calcular' (metretiké téchne) (Prot. 356e-357a). Esta ciencia métrica socrática es la mayor garantía de la conducta humana, pues nos desinstala del presente e incorpora al hedonismo un cierto consecuencialismo. Esta ciencia métrica nos libera del impacto de las apariencias que nos haría vacilar (Prot. 356c-d).

En armonía con esta teoría socrática, Epicuro propone la ponderación de las consecuencias del actuar difiriendo el placer presente en aras de la no aparición de un futuro dolor. La proyección del actuar en relación al futuro corresponde al cálculo (logismós) que indaga: “¿qué me sucederá si se realiza lo que mi deseo trata de conseguir? y ¿qué si no se realiza?"38. Es el cálculo quien dictamina cuándo "conviene privarse de algunos determinados placeres para no sufrir dolores más penosos" 39 . No es el hedonismo epicúreo el que requiere ser limitado por la razón ya que el placer se autoconstriñe desde la physis humana. Es el consecuencialismo, incipiente en Epicuro, el que requiere bridas racionales por las consecuencias de las elecciones. No es a raíz del placer que se procura al gozar por el que sobreviene el cálculo racional limitante, sino que esta irrupción del logismós se debe a lo que se logra (más allá del goce) por el hecho de gozar. De modo tal que si fuera posible vivir en el puro presente, sin transcurrir de tiempo, ningún placer habría de ser rechazado (salvo por otro mayor, igualmente presente), ni ningún dolor asumido. Sin el presupuesto de una continuidad temporal del yo, carecería de sentido diferir el placer o abrazarse al dolor.

Una de las imágenes más frecuentemente asociada al pla-

${ }^{38}$ Epicuro,SV 71

${ }^{39}$ Epicuro, Fragmentos, Usener 442. 
cer es la de la ceguera. Mas esta imagen no es muy ajustada, pues el deseo de placer ve lo presente, aun cuando no pueda prever lo lejano. Habría que hablar más bien de miopía hedonística, no de ceguera, pues "el apetito se atiene a lo inmediato, y es que el placer inmediato aparece como placer absoluto y bien absoluto porque se pierde de vista el futuro" ${ }^{\prime \prime}$. El placer ve lo presente porque a él está ligado, mas carece de previsión, pues la vista del placer es de simple alcance. El cálculo (logismós) no es el lazarillo del ciego placer, sino el catalejo de la miopía hedonística. Y es que, "a simple vista, los mismos tamaños, de cerca, parecen mayores y, de lejos, más pequeños" ${ }^{41}$. La simple vista del placer permite acceder a tácticas o adaptaciones de corto plazo, pero sólo el cálculo racional puede utilizar estrategias de largo alcance, pues a él se ha confiado el esfuerzo clarividente del futuro.

Quizá sea el propio Sócrates quien haya guiado las reflexiones epicúreas sobre este asunto, al asentar que no es el consecuencialismo el que limita al hedonismo, sino el mismo hedonismo el que utiliza como técnica al consecuencialismo, dejando de ser así un simple hedonismo sincrónico y transformándose en un hedonismo pancrónico. Pues si le preguntáramos a Sócrates si aventaja en algo el placer y el dolor del momento al placer y al dolor del futuro, nos contestaría,

¿acaso en otra cosa que en placer o en dolor? No es posible que en otro respecto. Ahora bien, si como un hombre que sabe pesar, reuniendo lo placentero y reuniendo lo doloroso, tanto lo de cerca como lo de lejos, lo colocas en la balanza, dime cuál es mayor.

${ }^{40}$ Aristóteles, Acerca del alma, L. III. Cap. $10^{\circ}, 433$ b.

${ }^{41}$ Platón, Protágoras 356 c (el subrayado es mío). 
Pues si pesas lo agradable frente a lo agradable, hay que preferir siempre lo que sea más en cantidad. Si los dolores frente a los dolores, lo menos y en menor cantidad. Si lo agradable frente a lo doloroso, que lo penoso sea superado por lo agradable; tanto si es lo inmediato por lo lejano, como si es lo de lejos por lo de más cerca, hay que elegir la acción en que eso se cumpla. Si los placeres son superados por los dolores, hay que abstenerse de ella. ¿Es que se puede ser de otro modo, señores? ${ }^{42}$.

\section{REFERENCIAS:}

\section{Epicuro:}

-Ep.Men.: Epístola a Meneceo (Trad. de Rafael Ojeda y Alicia Olabuenaga). En Epicuro, Madrid, Alhambra, 1985).

-MP: Máximas Principales (Trad. de Carlos García Gual y Eduardo Acosta). En Ética de Epicuro, Barcelona, Barreal Editores, 1973.

-SV: Gnomologio Vaticano o Exhortaciones (Trad. de Carlos García Gual y Eduardo Acosta). En Ética de Epicuro.

\section{Platón:}

-Fil.: Filebo (Trad. de Juan García Bacca). En Platón. Obras Completas. Caracas, Universidad Central de Venezuela, 1981, Tomo IV.

-Prot.: Protágoras. (Trad. de Carlos García Gual). En Diálogos, Madrid, Editorial Gredos, 1985, Tomo I.

\footnotetext{
${ }^{42}$ Pasquali, Antonio, Protágoras 356 b-c (el subrayado es mío)
} 